Aim of the study: Thromboprophylaxis in cancer patients during hospitalization reduces the risk of venous thromboembolism (VTE).

Material and methods: To assess the underuse and the overuse of thromboprophylaxis in cancer patients at a tertiary oncology department, we retrospectively analyzed 1983 consecutive hospitalizations of 498 cancer patients who received chemotherapy from October 2016 to May 2017. The Padua prediction score ( $\geq 4$ points) and Caprini risk assessment $(\geq 5$ points) were used to identify patients at high risk of VTE.

Results: The majority of individuals ( $n$ $=363,72.9 \%$ ) suffered from advanced lung cancer. We found that 419 (84.14\%) patients received thromboprophylaxis with enoxaparin $40 \mathrm{mg} \mathrm{qd}$, including 181 (43.2\%) individuals using concomitant mechanical thromboprophylaxis. As few as 44 (8.8\%) and $11(2.2 \%)$ patients did not receive thromboprophylaxis despite high VTE risk based on the Caprini risk assessment and Padua prediction score, respectively $(p<0.001)$. The number of patients without high risk of VTE, who received pharmacological thromboprophylaxis, was higher when the Padua prediction score was used compared with the Caprini risk assessment $(n=391$ [78.5\%] vs. $n=$ 210 [42.2\%], respectively; $p<0.001$ ). Three patients $(0.6 \%)$ experienced vascular events during hospital stay, including one symptomatic deepvein thrombosis. No major bleeding was observed. Predictors of thromboprophylaxis overuse were as follows: previous VTE and abnormal pulmonary function for both scales. Conclusions: This study shows that thromboprophylaxis in cancer in patients undergoing chemotherapy is suboptimal in Poland in part due to the use of various VTE risk scores yielding discrepant results in everyday practice.

Key words: thromboprophylaxis, cancer, hospitalisation, chemotherapy, the overuse of thromboprophylaxis.

Contemp Oncol (Pozn) 2018; 22 (1): 31-36 DOI: https://doi.org/10.5114/wo.2018.74391

\section{The comparison between Caprini and Padua VTE risk assessment models for hospitalised cancer patients undergoing chemotherapy at the tertiary oncology department in Poland: is pharmacological thromboprophylaxis overused?}

\author{
Robert F. Łukaszuk ${ }^{1}$, Justyna Dolna-Michno ${ }^{1}$, Krzysztof Plens ${ }^{2}$, \\ Grzegorz Czyżewicz ${ }^{3}$, Anetta Undas ${ }^{4,5}$
}

\author{
${ }^{1}$ Department of Pulmonology, John Paul II Hospital, Krakow, Poland \\ ${ }^{2} \mathrm{KCRI}$, Krakow, Poland \\ ${ }^{3}$ Department of Oncology, John Paul II Hospital, Krakow, Poland \\ ${ }^{4}$ Center for Research and Medical Technology, John Paul II Hospital, Krakow, Poland \\ ${ }^{5}$ Institute of Cardiology Jagiellonian University Medical College, Krakow, Poland
}

\section{Introduction}

Hospital stay precedes $10-20 \%$ of venous thromboembolism (VTE) episodes [1-3] and 10\% of inhospital deaths are related to VTE [4, 5]. Cancer is associated with a 4.1-fold greater risk of thrombosis [6, 7]. Approximately $20 \%$ of cancer patients develop VTE, which represents a frequent cause of death in these patients [8]. The key VTE risk factors are the primary site of cancer and the presence of distant metastasis [6, 8-12]. Patients with cancer and co-existing VTE have a 2-fold or greater mortality compared with those without thrombosis, even after adjusting for the disease stage [12, 13]. Lung cancer is the most common malignancy in malignancy-associated VTE patients [14]. Blom et al. [15] demonstrated that this risk among lung cancer patients increased 20-fold compared with the general population and patients diagnosed with lung adenocarcinoma have a higher risk of VTE than those suffering from squamous cell carcinoma. Over 3\% of lung cancer patients develop VTE within 2 years since diagnosis [16] and such episodes are associated with a 50\% higher risk of death within 2 years [17].

The aim of our study is to evaluate the risk of VTE among cancer inpatients and the use of thromboprophylaxis in order to assess the current trends in thromboprophylaxis among Polish inpatients.

\section{Material and methods}

We enrolled all consecutive patients aged 18 years or more with the confirmed diagnosis of cancer who were hospitalized from October 2016 to May 2017 in the Department of Oncology, John Paul II Hospital in Krakow, Poland. Solely patients who stayed in hospital for more than 24 hours were eligible. No exclusion criteria were used.

Demographic and clinical data were collected using questionnaires. The cancer stage was established based on clinical assessment and imaging based on the 8th Edition of the UICC TNM classification of Malignant Tumours [18] . Patients admitted to hospital more than once due to a cycle of chemotherapy were scored during the last stay within the given period of time. The study was conducted in accordance with local legal regulations. 
We used two validated scoring systems to identify patients at high risk for VTE when hospitalized, i.e. the Padua prediction score and Caprini VTE risk assessment [3, 19, 20]. The Padua prediction score, indicating a high risk, was defined as a score of 4 or higher. The Caprini VTE risk assessment identifies high risk as a score of 5 or higher. Pharmacological prophylaxis was administration of enoxaparin (40 mg once daily s.c. throughout hospitalisation). Mechanical prophylaxis (graduated compression stockings) was also recorded. The decision regarding thromboprophylaxis was at the managing physician's discretion. Not using thromboprophylaxis in patients at high risk for VTE identified using one of the scoring systems was recognized as the underuse of prophylaxis while the overuse was recognized as using any thromboprophylaxis in patients identified as at low risk.

\section{Statistical analysis}

Variables were presented as numbers and percentages for categorical variables or by median and interquartile range for continuous parameters. Nominal variables in the subgroups were compared with the Pearson's $\chi^{2}$ test or the Fisher's exact test for $2 \times 2$ tables as appropriate. Continuous variables were compared using the Mann-Whitney $U$ test. The comparison of two scoring systems was performed using the McNemara's test. To identify independent predictors of thromboprophylaxis overuse, univariate logistic regression analysis was performed. Associations between two variables were expressed as odds ratios (OR) along with $95 \%$ confidence intervals (95\% Cl). All p-values were two-sided and considered statistically significant if below 0.05. All calculations were done with JMP® ${ }^{\circledR}$ Version 13.1.0 SAS Institute Inc., Cary, NC.

\section{Results}

We enrolled 1983 consecutive hospitalisations of 498 individuals, including 318 (63.8\%) men (Table 1). Median age was 64.85 (range from 18 to 86 ) years. Median duration of hospitalisation was 3 (range from 2 to 5 ) days. The majority of individuals $(n=363$ [72.9\%]) suffered from lung cancer (Table 1). We identified 419 (84.14\%) patients who received thromboprophylaxis with enoxaparin including 181 (43.2\%) patients using concomitant mechanical thromboprophylaxis. There were no patients receiving the latter intervention among subjects without pharmacological thromboprophylaxis. One patient (0.2\%) suffered from cancer-related VTE diagnosed shortly before the hospital. None of the patients received oral anticoagulants. Participants received enoxyparixe according to scoring system results despite anti-platelet agents which they could use due to coronary artery disease. None of the individuals received anti-platelet agents as a type of thromboprophylaxis. The characteristic of study population was placed in Table 1. Types of chemotherapy in association with thromboprophylaxis are listed in Table 2. Chemotherapy was stopped in 12 (2.4\%) patients due to side effects.

\section{The Padua prediction score}

As shown in Table 3, using the Padua prediction score, we identified 39 (7.8\%) patients at high risk of VTE, includ- ing $28(71.8 \%)$ who received thromboprophylaxis. Eleven (28.2\%) high-risk patients did not receive thromboprophylaxis. There were no prophylaxis related intergroup differences depending on the type of cancer or its stage. Overall, the majority of inpatients did not have high VTE risk assessed using the Padua prediction score and $71.8 \%$ of high risk patients received thromboprophylaxis with the concomitant large overuse of pharmacological prophylaxis.

\section{Caprini VTE risk assessment}

We identified 257 (51.6\%) patients at high risk for VTE (Table 4), including 213 (82.9\%) who received thromboprophylaxis, and only 44 (17.1\%) who did not. The number of individuals at low risk for VTE was 241 (48.4\%), including 210 (87.1\%) receiving thromboprophylaxis despite the low risk.

\section{The comparison of two systems}

As shown in Table 5, the Caprini risk assessment classified more cancer inpatients into the high VTE risk group. The differences between two systems in terms of proportions of subjects at high and low VTE risk were highly significant.

\section{Predictors of the overuse of thromboprophylaxis}

Predictors of overused thromboprophylaxis were previous VTE and abnormal pulmonary function for both scales, while age over 75 years and swollen legs were identified for the Caprini risk assessment alone and varicose veins for Padua prediction score alone (Table 1). The type of chemotherapy did not affect the overuse of thromboprophylaxis.

\section{Clinical events during hospitalisation}

Three vascular thromboembolic events were recorded in 3 patients $(0.60 \%)$ during hospital stay. There were nonST elevation myocardial infarction, ST elevation myocardial infarction and right-sided deep vein thrombosis. No major bleeding was observed. Hemoptysis probably associated with lung cancer was observed in $8(1.6 \%)$ patients who reported this symptom prior to admission and received thromboprophylaxis on the ward without increased bleeding. No in-hospital deaths were observed.

\section{Discussion}

This study shows that nowadays thromboprophylaxis is suboptimal in lung cancer patients hospitalized for chemotherapy. Although patients eligible for thromboprophylaxis represented a small proportion of our study group when assessing the VTE risk using 2 scoring systems, most received the recommended subcutaneous $L M W H$. The overuse of pharmacological thromboprophylaxis was observed in our patients regardless of the scoring system used, although no major bleeding during hospital stay was observed. Given large differences in the proportions of cancer patients categorized into the high VTE risk groups between the 2 scoring systems, it might be speculated that advanced cancer inpatients undergoing chemotherapy should be evaluated using other systems than the two 
Table 1. The study population and thromboprophylaxis overuse predictors

\begin{tabular}{|c|c|c|c|c|c|c|c|c|}
\hline & \multirow[t]{2}{*}{$\begin{array}{l}\text { All patients } \\
(n=498)\end{array}$} & \multirow{2}{*}{$\begin{array}{l}\text { Patients who } \\
\text { received } \\
\text { thrombo- } \\
\text { prophylaxis } \\
(n=419)\end{array}$} & \multirow{2}{*}{$\begin{array}{l}\text { Patients who } \\
\text { did not receive } \\
\text { thrombo- } \\
\text { prophylaxis } \\
(n=79)\end{array}$} & \multirow{2}{*}{$p$-value } & \multicolumn{2}{|c|}{$\begin{array}{l}\text { Caprini risk assessment, } \\
\text { overuse predictors }\end{array}$} & \multicolumn{2}{|c|}{$\begin{array}{l}\text { Padua prediction score, } \\
\text { overuse predictors }\end{array}$} \\
\hline & & & & & OR $(95 \% \mathrm{Cl})$ & $p$-value & OR $(95 \% \mathrm{Cl})$ & $p$-value \\
\hline Age, years & $64.9(59.5-70)$ & $64.9(58.9-70.0)$ & $64.7(60.0-69.3)$ & 0.76 & $0.890(0.866-0.915)$ & $<0.001$ & $0.982(0.959-1.006)$ & 0.15 \\
\hline Men, $n(\%)$ & $318(63.8)$ & $274(65.3)$ & $44(55.7)$ & 0.09 & $1.180(0.807-1.726)$ & 0.40 & $1.596(1.033-2.466$ & 0.035 \\
\hline Overweight, n (\%) & $223(44.8)$ & $199(47.5)$ & $24(30.3)$ & 0.005 & $0.157(0.104-0.237)$ & $<0.001$ & $1.550(0.997-2.409)$ & 0.051 \\
\hline \multicolumn{9}{|l|}{ Comorbidities, $n$ (\%) } \\
\hline COPD or asthma & 93 (18.7) & 75 (17.9) & $18(22.8)$ & 0.31 & $0.696(0.435-1.115)$ & 0.13 & $0.691(0.411-1.160)$ & 0.16 \\
\hline Diabetes mellitus & $66(13.3)$ & $54(12.9)$ & $12(15.2)$ & 0.58 & $0.923(0.528-1.614)$ & 0.78 & $3.199(1.245-8.216)$ & 0.016 \\
\hline $\begin{array}{l}\text { Chronic kidney } \\
\text { disease }\end{array}$ & $8(1.6)$ & $8(1.9)$ & $0(0.0)$ & 0.37 & $0.400(0.274-0.584)$ & $<0.001$ & $0.552(0.359-0.849)$ & 0.007 \\
\hline $\begin{array}{l}\text { Arterial } \\
\text { hypertension or } \\
\text { coronary artery } \\
\text { disease }\end{array}$ & $208(41.8)$ & $167(39.9)$ & $41(51.9)$ & 0.05 & $0.378(0.104-1.370)$ & 0.14 & $0.834(0.454-1.533)$ & 0.56 \\
\hline Previous surgery & $58(11.6)$ & 55 (13.1) & $3(3.8)$ & 0.02 & $1.342(0.739-2.438)$ & 0.33 & $1.044(0.502-2.171)$ & 0.91 \\
\hline Varicose veins & $24(4.8)$ & $11(2.6)$ & $13(16.5)$ & $<0.001$ & - & - & $0.060(0.022-0.165)$ & $<0.001$ \\
\hline \multicolumn{9}{|c|}{ Thromboembolism, $n$ (\%) } \\
\hline Previous VTE & $6(1.2)$ & $3(0.7)$ & $3(3.8)$ & 0.05 & $0.280(0.032-2.415)$ & 0.25 & $0.268(0.053-1.348)$ & 0.11 \\
\hline $\begin{array}{l}\text { Previous VKA } \\
\text { treatment }\end{array}$ & $31(6.2)$ & $23(5.5)$ & $8(10.1)$ & 0.13 & $0.139(0.042-0.465)$ & 0.001 & $0.349(0.165-0.738)$ & 0.006 \\
\hline $\begin{array}{l}\text { Mechanical } \\
\text { thromboprophylaxis }\end{array}$ & $181(36.3)$ & $181(43.2)$ & $0(0.0)$ & 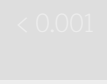 & - & - & - & - \\
\hline \multicolumn{9}{|c|}{ The histopathologic type of cancer, $n(\%)$} \\
\hline $\begin{array}{l}\text { Squamous-cell } \\
\text { cancer }\end{array}$ & $107(21.5)$ & $93(22.2)$ & $14(17.7)$ & 0.37 & $1.764(1.147-2.714)$ & 0.01 & $1.345(0.776-2.331)$ & 0.29 \\
\hline $\begin{array}{l}\text { Lung } \\
\text { adenocarcinoma }\end{array}$ & $193(38.8)$ & $167(39.9)$ & $26(32.9)$ & 0.24 & $0.844(0.584-1.219)$ & 0.37 & $1.256(0.803-1.963)$ & 0.32 \\
\hline $\begin{array}{l}\text { Small-cell lung } \\
\text { cancer }\end{array}$ & $125(25.1)$ & $98(23.4)$ & $27(34.2)$ & 0.04 & $0.615(0.402-0.942)$ & 0.03 & $0.549(0.346-0.874)$ & 0.011 \\
\hline Mesothelioma & $2(0.4)$ & $2(0.5)$ & $0(0.0)$ & 1.00 & - & - & - & - \\
\hline NOS & $47(9.4)$ & $39(9.3)$ & $8(10.1)$ & 0.82 & $1.277(0.699-2.334)$ & 0.43 & $1.014(0.487-2.112)$ & 0.97 \\
\hline Other cancers & $24(4.8)$ & $20(4.7)$ & $4(5.1)$ & 1.00 & $1.013(0.441-2.328)$ & 0.98 & $1.388(0.464-4.151)$ & 0.56 \\
\hline \multicolumn{9}{|c|}{ The stage of cancer, $n(\%)$} \\
\hline । & $1(0.2)$ & $1(0.2)$ & $0(0.0)$ & 1.00 & - & - & - & - \\
\hline$\|$ & $14(2.8)$ & $11(2.6)$ & $3(3.8)$ & 0.47 & $0.378(0.104-1.370)$ & 0.14 & $0.676(0.208-2.199)$ & 0.51 \\
\hline III & $161(32.3)$ & $145(34.6)$ & $16(20.2)$ & 0.01 & $1.180(0.807-1.726)$ & 0.39 & $1.865(1.132-3.074)$ & 0.014 \\
\hline IV & $322(64.6)$ & $262(62.5)$ & $60(75.9)$ & 0.02 & $0.924(0.636-1.340)$ & 0.68 & $0.582(0.361-0.938)$ & 0.026 \\
\hline \multicolumn{9}{|l|}{ VTE risk scores, (\%) } \\
\hline $\begin{array}{l}\text { Padua prediction } \\
\text { score: low risk } \\
\text { (< } 4 \text { points) }\end{array}$ & $459(92.2)$ & $391(78.5)$ & $68(21.5)$ & 0.03 & - & - & - & - \\
\hline $\begin{array}{l}\text { Padua prediction } \\
\text { score: high risk } \\
\text { ( } \geq 4 \text { points) }\end{array}$ & $39(7.8)$ & 28 (13.9) & $11(2.2)$ & 0.03 & - & - & - & - \\
\hline $\begin{array}{l}\text { Caprini VTE risk } \\
\text { assessment score: } \\
\text { low risk (< } 5 \text { points) }\end{array}$ & $241(48.4)$ & $206(41.4)$ & $35(7.1)$ & 0.43 & - & - & - & - \\
\hline $\begin{array}{l}\text { Caprini VTE risk } \\
\text { assessment score: } \\
\text { high risk ( } \geq 5 \text { points) }\end{array}$ & 257 (51.6) & $213(42.8)$ & $44(8.8)$ & 0.43 & - & - & - & - \\
\hline
\end{tabular}


Table 2. Agents used during chemotherapy in the study patients

\begin{tabular}{lcccc} 
Medication, $n(\%)$ & $\begin{array}{c}\text { The whole } \\
\text { population } \\
(n=498)\end{array}$ & $\begin{array}{c}\text { Patients who received } \\
\text { thromboprophy-laxis } \\
(n=419)\end{array}$ & $\begin{array}{c}\text { Patients who did not } \\
\text { receive thromboprophylaxis } \\
(n=79)\end{array}$ & $\begin{array}{c}p \text {-value } \\
\text { EGFR inhibitor }\end{array}$ \\
\hline $45(9.0)$ & $42(10.0)$ & $3(3.8)$ & 0.08 \\
Chemotherapy based on 5-fluorouracil & $20(4.0)$ & $19(4.5)$ & $1(1.3)$ & 0.22 \\
Platine-based chemotherapy agents & $347(69.7)$ & $288(68.7)$ & $67(84.8)$ & 0.01 \\
Other chemotherapeutics & $79(15.9)$ & $64(15.3)$ & $14(17.7)$ & 0.58 \\
Dexamethasone & $453(91.0)$ & $377(90.0)$ & $76(96.2)$ & 0.08
\end{tabular}

Data are presented number (percentage)

EGFR - epidermal growth factor receptor

Table 3. Use of thromboprophylaxis according to Padua prediction score

\begin{tabular}{|c|c|c|c|c|c|c|}
\hline & $\begin{array}{l}\text { Patients who should } \\
\text { receive thrombopro- } \\
\text { phylaxis }\end{array}$ & $\begin{array}{c}\text { Patients who } \\
\text { should not receive } \\
\text { thromboprophylaxis }\end{array}$ & $\begin{array}{l}\text { Patients who } \\
\text { received thrombo- } \\
\text { prophylaxis }\end{array}$ & $\begin{array}{l}\text { Patients who did not } \\
\text { receive thrombopro- } \\
\text { phylaxis despite indication }\end{array}$ & $\begin{array}{l}\text { Patients received } \\
\text { thromboprophylaxis } \\
\text { without indication }\end{array}$ & $p$-value \\
\hline $\begin{array}{l}\text { Padua } \\
\text { prediction score } \\
\geq 4 \text { points, } n(\%)\end{array}$ & $39(7.8)$ & $459(92.2)$ & $28(5.6)$ & $11(2.2)$ & $391(78.5)$ & $<0.001$ \\
\hline \multicolumn{7}{|c|}{ The histopathological type of cancer, $n$ (\%) } \\
\hline $\begin{array}{l}\text { Squamous-cell } \\
\text { cancer }\end{array}$ & $7(17.9)$ & $100(21.8)$ & $93(22.2)$ & $2(18.2)$ & $88(22.5)$ & 0.80 \\
\hline $\begin{array}{l}\text { Lung } \\
\text { adenocarcinoma }\end{array}$ & $15(38.5)$ & $178(38.8)$ & $167(39.9)$ & $4(36,4)$ & $156(39.9)$ & 0.97 \\
\hline $\begin{array}{l}\text { Small-cell lung } \\
\text { cancer }\end{array}$ & $15(38.5)$ & $110(23.9)$ & $98(23.4)$ & $5(45.4)$ & $88(22.5)$ & 0.06 \\
\hline Mesothelioma & $0(0.0)$ & $2(0.4)$ & $2(0.5)$ & $0(0.0)$ & $2(0.5)$ & 0.90 \\
\hline NOS & $2(5.1)$ & $45(9.8)$ & $39(9.3)$ & $0(0.0)$ & $37(9.5)$ & 0.06 \\
\hline Other cancers & $0(0.0)$ & $24(5.2)$ & $20(4.8)$ & $0(0.0)$ & $20(5.1)$ & 0.35 \\
\hline \multicolumn{7}{|c|}{ The stage of cancer, $n(\%)$} \\
\hline । & $0(0.0)$ & $1(0.2)$ & $1(0.2)$ & $0(0.0)$ & $1(0,2)$ & 0.95 \\
\hline ॥ & $1(2.6)$ & $13(2.8)$ & $11(2.6)$ & $0(0.0)$ & $10(2.5)$ & 0.81 \\
\hline III & $12(30.8)$ & $149(32.5)$ & $145(34.6)$ & $4(36.4)$ & $137(35.1)$ & 0.78 \\
\hline IV & $26(66.7)$ & $296(64.5)$ & $262(62.5)$ & $7(63.6)$ & $243(62.1)$ & 0.83 \\
\hline
\end{tabular}

Data are presented number (percentage)

most commonly used in medical non-cancer hospitalized patients.

Our study reported that prophylactic LMWH is more commonly used among lung cancer inpatients compared with those suffering from a wide range of pulmonary diseases in the same Polish tertiary hospital [20]. Awareness of the VTE risk, as the most common preventable cause of death in hospitals, has increased in Poland, where several local guidelines have been issued over the last 10 years [10, 17]. Polish guidelines on the prevention of VTE in patients with cancer conservatively treated have recommended using the Padua Prediction Score to estimate the risk of VTE [17]. However, the current study showed that this system identifies high VTE risk in a small subset of hospitalized patients undergoing chemotherapy and the proportion is much lower compared with another system introduced by Caprini. It indicates that a real clinical value of the current assessment models for cancer inpatients should be re-evaluated and there is a need for modifications of the scoring systems to improve VTE risk assessment in cancer inpatients.

To our knowledge, the two scoring systems used in this study have not been tested in cancer inpatients yet. Our study suggests that in cancer patients the Caprini risk assessment might be preferred. Larger prospective studies are needed to validate this observation, which appears in line with other studies in different inpatient groups. Liu X et al. showed in Chinese inpatients that Caprini risk assessment had a higher sensitivity and both positive and negative predictive values than the Padua prediction score in hospitalized patients [21]. Zhou HX et al. reported similar findings and also noticed that the Caprini risk assessment score could be helpful in predicting the risk of recurrent VTE in inpatients [22].

A surprising overuse of thromboprophylaxis with $\mathrm{LMWH}$ in cancer inpatients observed in the current study deserves a comment. It might be speculated that the overuse of prophylactic LMWH was associated with physician's con- 
Table 4. Use of thromboprophylaxis according to Caprini VTE risk assessment

\begin{tabular}{|c|c|c|c|c|c|c|}
\hline & $\begin{array}{l}\text { Patients who } \\
\text { should receive } \\
\text { thrombopro- } \\
\text { phylaxis }\end{array}$ & $\begin{array}{l}\text { Patients who } \\
\text { should not receive } \\
\text { thrombopro- } \\
\text { phylaxis }\end{array}$ & $\begin{array}{l}\text { Patients who } \\
\text { received } \\
\text { thrombopro- } \\
\text { phylaxis }\end{array}$ & $\begin{array}{l}\text { Patients who did not } \\
\text { receive thrombopro- } \\
\text { phylaxis despite } \\
\text { indication }\end{array}$ & $\begin{array}{l}\text { Patients who } \\
\text { received thrombo- } \\
\text { prophylaxis } \\
\text { without indication }\end{array}$ & $p$-value \\
\hline $\begin{array}{l}\text { Caprini VTE risk } \\
\text { assessment } \geq 5 \text { points, } \\
n(\%)\end{array}$ & $257(51.6)$ & $241(48.4)$ & $213(42.8)$ & $44(8.8)$ & $210(42.2)$ & $<0.001$ \\
\hline \multicolumn{7}{|c|}{ The histopathologic type of cancer, $n$ (\%) } \\
\hline Squamous-cell cancer & $44(17.1)$ & $63(26.1)$ & $93(22.2)$ & $7(15.9)$ & $56(26.7)$ & 0.03 \\
\hline Lung adenocarcinoma & $103(40.1)$ & $90(37.3)$ & $167(39.8)$ & $11(25,0)$ & $75(35.7)$ & 0.05 \\
\hline Small-cell lung cancer & $76(29.6)$ & $49(20.3)$ & $98(23.4)$ & $19(43.2)$ & $41(19.5)$ & 0.01 \\
\hline Mesothelioma & $0(0.0)$ & $2(0.8)$ & $2(0.5)$ & $0(0.0)$ & $2(0.9)$ & 0.28 \\
\hline NOS & $24(9.3)$ & $23(9.5)$ & $39(9.3)$ & $7(15.9)$ & $22(10.5)$ & 0.25 \\
\hline Other cancers & $10(3.9)$ & $14(5.8)$ & $20(4.8)$ & $0(0.0)$ & $14(6.7)$ & 0.33 \\
\hline \multicolumn{7}{|c|}{ The stage of cancer, $n(\%)$} \\
\hline । & $0(0.0)$ & $1(0.4)$ & $1(0.2)$ & $0(0.0)$ & $1(0.5)$ & 0.53 \\
\hline$\|$ & $9(3.5)$ & $5(2.1)$ & $11(2.6)$ & $1(2.3)$ & $3((1.4)$ & 0.33 \\
\hline III & $86(33.5)$ & 75 (31.1) & $145(34.6)$ & $12(27.3)$ & 71 (33.8) & 0.62 \\
\hline IV & $162(63.1)$ & $160(66.4)$ & $262(62.5)$ & $31(70.4)$ & $131(62.4)$ & 0.53 \\
\hline
\end{tabular}

Data are presented number (percentage)

Table 5. Comparison of two scoring systems in the study population

\begin{tabular}{|c|c|c|c|}
\hline & Caprini VTE risk assessment & Padua prediction score & $p$-value \\
\hline Patients who should receive thromboprophylaxis & $257(51.6)$ & $39(7.8)$ & $<0.001$ \\
\hline Patients who should not receive thromboprophylaxis & $241(48.4)$ & $459(92.2)$ & $<0.001$ \\
\hline Patients who received thromboprophylaxis & $213(42.8)$ & $28(5.6)$ & $<0.001$ \\
\hline Patients who did not receive thromboprophylaxis despite indication & $44(8.8)$ & $11(2.2)$ & $<0.001$ \\
\hline Patients who received thromboprophylaxis without indication & $210(42.2)$ & $391(78.5)$ & $<0.001$ \\
\hline
\end{tabular}

cerns for a significant risk of VTE among cancer patients, which have been observed also by us. Van Es et al. showed that $6.1 \%$ of patients with solid cancer developed VTE and the prediction scores performed poorly in predicting VTE in cancer patients [23]. We noticed that most of the overuse predictors for both scales were well-established risk factors of developing VTE [1]. Given high cost of pharmacological thromboprophylaxis for our healthcare system when overused, administration of LMWH in hospitalized cancer patients should be reconsidered and used when indicated. Nevertheless, bleeding complications in patients with advanced lung cancer who simultaneously received chemotherapy and thromboprophylaxis have been observed infrequently in the published reports, i.e. in 1-3.7\% of patients [24]. Our analysis showed that knowledge of benefits from thromboprophylaxis used in cancer patients among oncologists is larger than 10 years ago, when the ENDORSE study had been performed and showed no prophylaxis in $67.5 \%$ of medical patients, including cancer patients [2].
Thromboprophylaxis with enoxaparin in cancer inpatients was found to be efficacious, with 3 individuals who developed 3 vascular events, including one venous and 2 arterial episodes. This confirms that thromboprophylaxis with $\mathrm{LMWH}$ is not effective in preventing myocardial infarction in subjects with large atherosclerotic burden. Moreover, cancer may increase the risk of $\mathrm{MI}$ and ischemic stroke [25]. Such prothrombotic potential related to cancer cannot be abolished using prophylactic doses of enoxaparin which is effective in preventing VTE, with a single case of its failure, namely venous thrombosis despite prophylaxis.

This study has several limitations. It is retrospective, which implies inherent problems with data acquisition and its completeness. Patients were not screened for asymptomatic VTE events, therefore the number of episodes could be underrepresented in this study. Long-term follow-up in terms of occurrence of VTE after discharge was beyond scope of the study. Given growing use of non-vitamin $\mathrm{K}$ antagonist oral anticoagulants worldwide, their role in VTE prevention in cancer remains to be established [26]. 
Regarding the data presentation, $\mathrm{R}^{2}$ measures for logistic regression models (i.e. Cox and Snell $R^{2}$ ) were not reported based on lower priority for such measures as compared to $\mathrm{OR}$ and $95 \% \mathrm{Cl}$ [27]. We cannot exclude using vitamin supplements which might affect thrombosis risk, however it is unlikely that this factor impacted our results.

In conclusion, the use of thromboprophylaxis in advanced cancer patients hospitalized due to chemotherapy is suboptimal. We showed the overuse of thromboprophylaxis in the oncology department however without significant bleeding risk. Our study suggests that both scoring systems are not consistent in the risk evaluation among hospitalized cancer patients and there is a need for better scoring systems to be applied in this disease.

The authors declare no conflict of interest.

\section{References}

1. Steuer C, Behera M, Kim S, et al. Predictors and outcomes of venous thromboembolism in hospitalized lung cancer patients: A Nationwide Inpatient Sample database analysis. Lung Cancer 2015; 88: 80-4.

2. Cohen AT, Tapson VF, Bergmann JF, et al. ENDORSE Investigators. Venous thromboembolism risk and prophylaxis in the acute hospital care setting (ENDORSE study): a multinational cross-sectional study. Lancet 2008; 371: 387-94.

3. Kahn SR, Lim W, Dunn AS et al. Prevention of VTE in nonsurgical patients: Antithrombotic Therapy and Prevention of Thrombosis, 9th ed. American College of Chest Physicians Evidence -Based Clinical Practice Guidelines. Chest 2012; 141: 195-226.

4. Lindblad B, Sternby NH, Bergqvist D. Incidence of venous thromboembolism verified by necropsy over 30 years. BMJ 1991; 302: 709-11.

5. Kakkar N, Vasishta RK. Pulmonary embolism in medical patients: an autopsy-based study. Clin Appl Thromb Hemost. 2008; 14: 159-67.

6. Khorana AA, Francis CW, Culakova E, Kuderer NM, Lyman GH. Frequency, risk factors, and trends for venous thromboembolism among hospitalized cancer patients. Cancer 2007; 110: 2339-46.

7. Heit JA, Silverstein MD, Mohr DN, Petterson TM, O'Fallon WM, Melton LJ III. Risk factors for deep vein thrombosis and pulmonary embolism: a population-based case-control study. Arch Intern Med 2000; 160: 809-15.

8. Blom JW, Doggen CJ, Osanto S, Rosendaal FR. Malignancies, prothrombotic mutations, and the risk of venous thrombosis. JAMA 2005; 293: 715-22.

9. Khorana AA, Connolly GC. Assessing risk of venous thromboembolism in the cancer patient. J Clin Oncol 2009; 27: 4839-47.

10. Zawilska K, Bała M, Błędowski P, et al. Polish guidelines for the prevention and treatment of venous thromboembolism. 2012 update. Pol Arch Med Wewn 2012; 122: 3-74.

11. Sallah S, Wan JY, Nguyen NP. Venous thrombosis in patients with solid tumours: determination of frequency and characteristics. Thromb Haemost 2002; 87: 575-9.

12. Chew HK, Wun T, Harvey D, Zhou H, White RH. Incidence of venous thromboembolism and its effect on survival among patients with common cancers. Arch Intern Med 2006; 166: 458-64.

13. Khorana AA, Francis CW, Culakova E, Lyman GH. Risk factors for chemotherapy-associated venous thromboembolism in a prospective observational study. Cancer 2005; 104: 2822-9.

14. Sorensen HT, Mellemkjaer L, Olsen JH, Baron JA. Prognosis of cancers associated with venous thromboembolism. N Engl J Med 2000; 343: 1846-50.

15. Blom JW, Osanto S, Rosendaal FR. The risk of a venous thrombotic event in lung cancer patients: higher risk for adenocarcinoma than squamous cell carcinoma. J Thromb Haemost 2004; 2: 1760-5.
16. Krasiński Z, Krasińska B, Dzieciuchowicz Ł, Urbanek T, Gabriel M. Heparins in cancer-associated venous thrombosis. Pol Arch Med Wewn 2016; 126: 419-42.

17. Wojtukiewicz MZ, Sierko E, Tomkowski W, et al. Guidelines for the prevention and treatment of venous thromboembolism in patients with cancers treated conservatively. Oncol Clin Pract 2016; 12: 67-91.

18. Brierley JD, Gospodarowicz MK, Wittekind C, TNM Classification of Malignant Tumours Eighth edition. Wiley -Blackwell 2016.

19. Farge D, Bounameaux H, Brenner B, Cajfinger F, Debourdeau P, Khorana AA, Pabinger I, Solymoss S, Douketis J, Kakkar A . International clinical practice guidelines including guidance for direct oral anticoagulants in the treatment and prophylaxis of venous thromboembolism in patients with cancer. Lancet Oncol 2016; 17: 452-66.

20. Łukaszuk R, Plens K, Undas A. Real-life use of thromboprophylaxis in patients hospitalized for pulmonary disorders: a single-center retrospective study Adv Clin Exp Med 2018; 27: 237-43.

21. Liu X, Liu C, Chen X, Wu W, Lu G. Comparison between Caprini and Padua risk assessment models for hospitalized medical patients at risk for venous thromboembolism: a retrospective study. Interact Cardiovasc Thorac Surg 2016; 23: 538-43.

22. Zhou HX, Peng LQ, Yan Y, Yi Q, Tang YJ, Shen YC, Feng YL, Wen FQ. Validation of the Caprini risk assessment model in Chinese hospitalized patients with venous thromboembolism. Thromb Res 2014; 21: 261-72.

23. Van Es N, Di Nisio M, Cesarman G, et al. Comparison of risk prediction scores for venous thromboembolism in cancer patients: a prospective cohort study. Haematologica 2017; 102: 1494-501.

24. Verso M, Gussoni G, Agnelli G. Prevention of venous thromboembolism in patients with advanced lung cancer receiving chemotherapy: a combined analysis of the PROTECHT and TOPIC-2 studies. J Thromb Haemost 2010; 8: 1649-51.

25. Rogers L. Cerebrovascular complications in cancer patients. Neurologic Clinics 2003; 21: 167-92.

26. Weitz J, Jaffer IH. Optimizing the safety of treatment for venous thromboembolism in the era of direct oral anticoagulants. Pol Arch Med Wewn 2016; 126: 688-96.

27. Hosmer Jr DW, Lemeshow S. Applied logistic regression. $2^{\text {nd }}$ ed. John Wiley \& Sons, New York 2004; 167.

\section{Address for correspondence}

\section{Robert F. Łukaszuk}

Department of Pulmonology

John Paul II Hospital in Krakow

Prąnicka 80

31-202 Krakow, Poland

e-mail: robertlukaszuk@yahoo.com

Submitted: 15.12 .2017

Accepted: $\quad 5.02 .2018$ 